\title{
超臨界窒素中におけるピストン効果の可視化に関する研究
}

\author{
中納 暁洋 ${ }^{\dagger}$ ，白石 正夫，村上 正秀* \\ 通商産業省工業技術院機械技術研究所 つくば市並木 1-2（ ${ }^{\dagger}$ E-mail : akihiro@mel.go.jp) \\ * 筑波大学機能工学系 つくば市天王台 1-1-1
}

(2000 年 6 月 28 日受理)

\section{Visualization Study of Piston Effect in Supercritical Nitrogen}

\author{
Akihiro NAKANO, Masao SHIRAISHI and Masahide MURAKAMI* \\ Mechanical Engineering Laboratory, Agency of Industrial Science and Technology, \\ Ministry of International Trade and Industry, 1-2 Namiki, Tsukuba 305-8564 \\ * Institute of Engineering Mechanics and Systems, University of Tsukuba, \\ 1-1-1 Tennodai, Tsukuba 305-8573
}

(Received June 28, 2000)

\begin{abstract}
Synopsis: The heat transport phenomena near the critical point of fluids were investigated in this study. The very-high thermal compressibility and very-low thermal diffusivity near the critical point of fluids affect thermal energy propagation and lead to the formation of weak acoustic waves as the carrier of thermal energy. The heat transport phenomenon is called the "piston effect", which is one of the thermodynamic phenomena that occur near the critical point of substances. The piston effect in supercritical nitrogen was investigated using a laser holography interferometer. An experimental apparatus was designed for the visualization study of the piston effect in supercritical nitrogen. Heat was added in step functions from a planar heater in a facedown orientation on the ceiling. The infinite-fringe method with a double-exposure technique was used in this experiment. We successfully observed a heat transport phenomenon piston effect, which is considered to be the 4th mechanism of heat transfer.
\end{abstract}

Keywords: piston effect, supercritical fluids, nitrogen, heat transfer, laser holographic interferometer

\section{1. はじめに}

近年, エネルギー・環境技術分野において, 超臨界 流体を利用した技術が注目されている。そのような応 用技術に対し, 超臨界流体の熱的特性についての把握 は必要不可欠である。特に臨界点では, 比熱などの熱 物理学量が発散するため, 臨界点近傍における超臨界 流体の熱的振る舞いの把握は重要となる. 1984 年, K. Nitsche と J. Straub らが弾道ロケットTEXUS を用 いた臨界点近傍での比熱計測に関する微小重力実験 1) で，異常な熱の伝播を観測した．また，D-1 スペース ラボフライト実験では, 更に詳細な比熱計測を行うと 共に，その熱輸送現象に関する熱緩和時間の計測が,
ホログラフィー干渉計を用いて行われた ${ }^{2)}$. その後, 多くの研究者によって研究が行われ, 現在その現象は, 熱が音波として伝わる現象“ピストン効果 (piston effect)”として知られている。なお，ピストン効果は 熱伝導, 対流, 熱輻射に次ぐ, 第 4 の熱輸送機構とし て認知されている ${ }^{3)}$. ピストン効果による熱の伝播に ついては小貫らが，臨界点近傍における流体の高圧縮 性と低熱拡散性により発現することを，巨視的な熱力 学的観点から明確な説明を与えた ${ }^{4)}$. その後, 多くの 研究者が数值シミュレーションを行うことによりこれ を確認している ${ }^{5.6)}$. 次に実験について述べると, 地 上でピストン効果を観測するには，対流の発生がこの 現象を隠蔽し非常に困難となるため, 多くの研究者は 
微小重力環境下において, この現象についての研究を 行なってきた ${ }^{2,37.87}$. 地上実験でピストン効果を観測 した例は非常に少なく ${ }^{9-11)}$ ，また，明確にこの現象を 可視化したという報告はこれまでされていない.前回, 我々は本誌上において, 窒素の臨界点近傍での熱輸送 現象をレーザーホログラフィー干渉計で捉えることに 成功した旨の報告を行った ${ }^{12)}$. この時は実験セルの 下部から加熱を行い, 自然対流とピストン効果により 熱が輸送される領域が共存する状態を捉えた旨の実験 結果を伝えた. 今回は, 実験セルの上部から平板ヒー ターで加熱を行うことにより，自然対流の発生を抑制 し，ピストン効果のみをより鮮明に捉えることを試み た. ピストン効果により発現する特異な温度分布の形 成過程を可視化実験で捉えたので，その結果について 報告する。

\section{2. 実験装置}

超臨界窒素実験セルを可視化用クライオスタット内 に納め, 2 光路 2 重露光型レーザーホログラフィー干 渉計を組み, 可視化実験を行った. クライオスタット の構造, 光学系の配置, 及び撮影手順については前報 を参照されたい ${ }^{12}$. Fig. 1 に実験セルの概略を示す. 本実験では重力による自然対流の発生を抑えるため, 平板ヒーターの加熱面を下向きに実験セルの天井板に これを設置し, 加熱を実験セルの上部から行った. 実 験セルは幅 $16 \mathrm{~mm}$ 、奥行き $65 \mathrm{~mm}$ 、高さが $38 \mathrm{~mm}$ の 直方体である. 天井板に平板ヒーターを張付けたため,

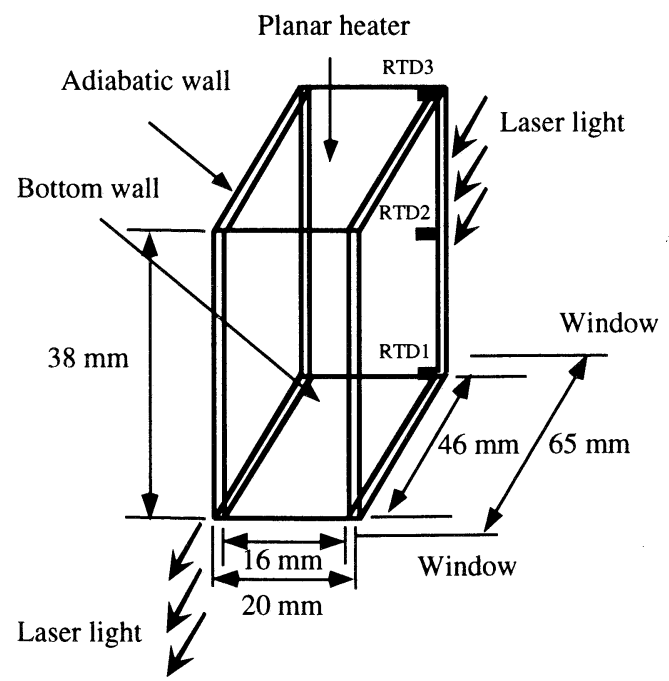

Fig. 1 Schematic illustration of the experimental cell.
前回報告した実験セルに比べ, 高さが $2 \mathrm{~mm}$ 程低く なっている. 第一露光で加熱を行う前の温度場, 密度 場をホログラフィー乾板上に記録した後，加熱を開始 し，予め設定した加熱時間になると第二露光を行い, その状態を同一乾板上に記録した.このホログラフィ 一乾板を後ほど現像・再生することにより，第一露光 と第二露光間の実験セル内部の温度変化, 又は密度変 化を干渉縞として捉えた。更に，実験セル内の温度を モニターするため, 実験セル上部, 中央, 下部にセル ノックス温度計 RTD3，RTD2， RTD1 を設置した。

\section{3. ピストン効果について}

実験に先立ち, ピストン効果により熱が輸送される 場合と, 熱伝導により熱が輸送される場合との差異を 明確にするため, 数值シミュレーションを行った. 解 析に際し，次に示す連立方程式を解いた ${ }^{6,13)}$.

$$
\begin{aligned}
& \frac{\partial \rho}{\partial t}+\frac{\partial\left(\rho V_{i}\right)}{\partial x_{i}}=0 \\
& \rho \frac{\partial V_{i}}{\partial t}+\rho V_{j} \frac{\partial V_{i}}{\partial x_{j}}=-\frac{\partial P}{\partial x_{i}}+\frac{\partial}{\partial x_{i}}\left(\zeta \frac{\partial V_{k}}{\partial x_{k}}\right) \\
& +\frac{\partial}{\partial x_{j}}\left[\eta\left(\frac{\partial V_{i}}{\partial x_{j}}+\frac{\partial V_{j}}{\partial x_{i}}-\frac{2}{3} \delta_{i k} \frac{\partial V_{k}}{\partial x_{k}}\right)\right] \\
& \frac{d Q}{d t}=\frac{\partial}{\partial x_{i}}\left(\varepsilon \frac{\partial T}{\partial x_{i}}\right)+\sigma_{i j} \frac{\partial V_{i}}{\partial x_{i}}
\end{aligned}
$$

$$
\frac{d P}{d t}=\frac{1}{\rho \alpha_{T}} \frac{d \rho}{d t}+\frac{\beta}{\alpha_{T}} \frac{d T}{d t}
$$

式(1)〜(4)はそれぞれ, 連続の式, 運動方程式, エネ ルギーバランスの式, 状態方程式を示す.ここで $\rho, V$, $P, T, t$ 滵度, 速度, 圧力, 温度, 時間を示し, $\eta, \zeta, \varepsilon, \alpha_{\mathrm{T}}, \beta$ は粘性係数, 体積粘性係数, 熱伝導率, 等温圧縮率，体膨張係数をそれぞれ示す。また Q は 単位体積あたりの熱エネルギーを表し， $\sigma_{\mathrm{ij}}^{\prime}$ と $\delta_{\mathrm{ik}}$ は 粘性ストレステンソルとユニットテンソルをそれぞれ 表す. Fig. 2a に窒素の臨界点近傍における超臨界域 で加熱を行った場合の温度分布の時間変化について示 す. 計算モデルは 1 次元とし, 長さ $1 \mathrm{~cm}$ の細管中に 臨界温度より $100 \mathrm{mK}$ ほど温度が高く, 圧力 3.4152 $\mathrm{MPa}$ の状態の超臨界窒素が納められている．右側の 
壁は温度一定とし，左側の壁の温度が $5 \mathrm{mK}$ 程ステッ プ的に上昇した時の熱の伝わり方を調べた. 比較のた め, Fig. 2b に $75 \mathrm{~K}, 0.1 \mathrm{MPa}$ の液体窒素の場合の計 算結果を示す. 1 次元系の計算であるので, Fig. 2b は熱伝導で熱が伝わつた時の温度分布の時間変化を示 している. Fig. 2a に示した温度分布は Fig. 2b と比べ, 全く異なっていることが分かる. Fig. 2a はピストン 効果で熱が輸送された時の典型的な温度分布を示して おり, 超臨界窒素の場合も臨界点近傍での流体の高圧 縮性と低熱拡散性により, この様に特異な温度分布が 形成されることが分かった ${ }^{12}$. まず，加熱された七 一ター面と流体の間で薄い熱拡散性の境界層が形成さ れ，それが流体の高圧縮性により膨張する。これがピ ストンのように働き圧力波（音波）が発生し流体中を 伝わる. そして, 反対側の壁に到達すると反射しこれ を繰り返す．断熱条件下で圧力波は熱へと変換され流 体が温められることにより，この様に両端の壁近傍以 外の大部分の領域で一様な温度分布が形成される．よ って, ピストン効果で熱が輸送される場合, 温度分布 に 2 つの大きな特徵が現れることが判明した.一つは,
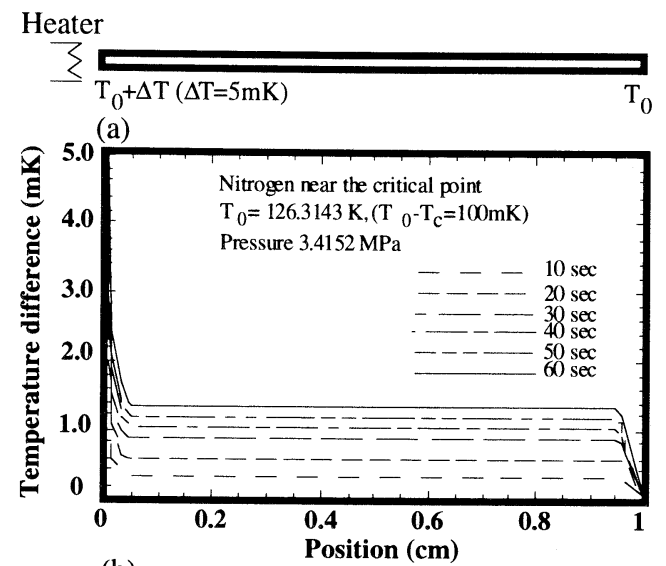

(b)

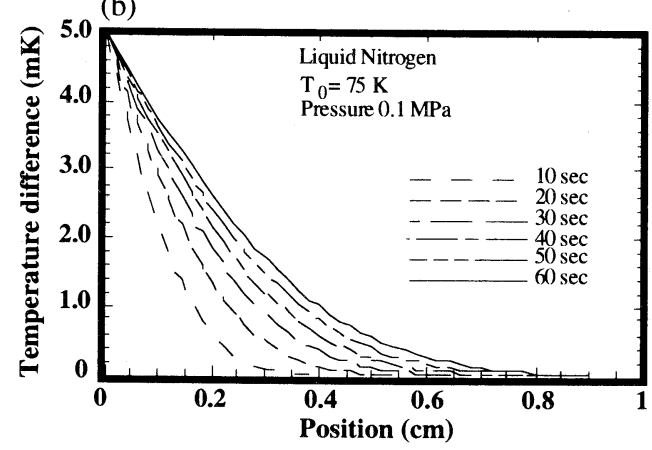

Fig. 2 Calculation results of the one-dimensional model.
空間的に一様な温度分布が形成されることと，もう一 つは壁の温度を固定したことにより，両端の壁近傍で 急峻な温度勾配が現れることである.これら 2 つ特 徵を実験で捉えることができれば，ピストン効果によ る熱輸送現象を検証することができると考え，レーザ 一ホログラフィー干渉計を用いて可視化実験を試みた.

\section{4. 実験結果と考察}

臨界点近傍において最も支配的な熱輸送機構は自然 対流であることから,ピストン効果を捉えるためには, 自然対流の発生を抑制させる必要がある. 自然対流が 生じるか否かの不安定限界は臨界レイリー数 $R a$ で規 定される ${ }^{14)}$.

$$
R a=\frac{\beta g l^{3} \Delta T}{v \chi}
$$

ここで $ぬ$ は温度伝導率, vは動粘性率, $g$ は重力加速度, $l$ と $\Delta T$ は 2 つ壁の間の距離と温度差をそれぞれ表す。 本実験のように流体層が一定温度の 2 つの固体の平面 に挟まれている場合, 対流は $R a>1710$ で発生する. 臨界点で防無限大となることから, 臨界点近傍にお いて Ra は非常に大きな值をとり, 対流が発生しやす くなる，例えば，臨界温度より $1 \mathrm{~K}$ 高い $127.2143 \mathrm{~K}$, 圧力 $3.5695 \mathrm{MPa}$ の条件で, 実験セルの形状を考慮し 計算を行うと, $\Delta T$ が約 $0.2 \mathrm{nK}$ で対流が発生する. 対 流の発生はピストン効果の捕捉を妨げることから，今 回は前回報告した対流の発生を抑制させる初期温度分 布の形成に加え, セル上部から加熱を行い, 対流の発 生に対する抑制策を講じた。

Fig. 3 に加熱を行わない熱流束 $\mathrm{q}=0 \mathrm{~W} / \mathrm{m}^{2}$ の時の 実験結果をバックグラウンドデータとして示す. Fig. 3a〜d は各時間を経たホログラフィー画像であり, Fig. 3e は Fig. 3a 撮影時における温度デー夕を示す. 図中, $\mathrm{T}_{\mathrm{RTD}}$ と $\mathrm{T}_{\mathrm{RTD1}}$ は初期状態のセル上部と下部の温度を, $\Delta \mathrm{T}$ はセル内平均温度と内部圧力から算出した 1 干渉 縞間隔あたりの平均温度分解能を示す. また P は内 部圧力, $\Delta \mathrm{t}$ は第一露光と第二露光の間の時間間隔を 表す. $\Delta \mathrm{t}$ は同時に加熱開始からの経過時間を表すこ とになるが，この場合は加熱を行っていない. Fig. 3a では干渉縞が中央やや上側に集中しているが,ここは, 系が臨界点に達する前に気液界面が存在していた位置 である，前報 ${ }^{12}$ で報告したように，相変化は気液界 面で始まることから，相転移を終えた直後の当該状態 において，この位置に干渉縞が集中することは, 温度 
(a)

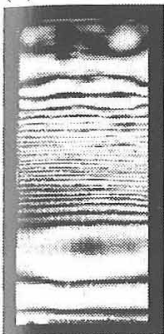

(b)

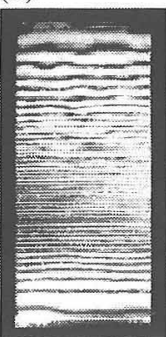

(c)

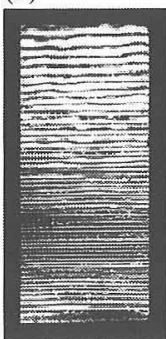

(d)

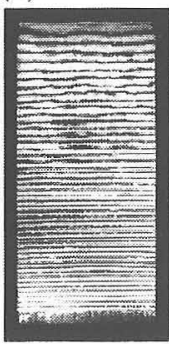

$T_{R T D 3}=127.76 \mathrm{~K} \quad T_{R T D 3}=129.58 \mathrm{~K} \quad T_{R T D 3}=129.06 \mathrm{~K} \quad T_{P_{R D} 3}=129.58 \mathrm{~K}$ $T_{\text {RTD } 1}=124.65 \mathrm{~K} \quad T_{\text {RTD } 1}=125.34 \mathrm{~K} \quad T_{\text {RTD } 1}=126.74 \mathrm{~K} \quad T_{\text {RTDI }}=126.74 \mathrm{~K}$ $\Delta \mathrm{T}=1.79 \mathrm{mK} \Delta \mathrm{T}=0.99 \mathrm{mK} \Delta \mathrm{T}=0.88 \mathrm{mK} \Delta \mathrm{T}=1.07 \mathrm{mK}$ $\mathrm{P}=3.619 \mathrm{MPa} \mathrm{P}=3.707 \mathrm{MPa} P=3.825 \mathrm{MPa} \mathrm{P}=3.903 \mathrm{MPa}$ $\Delta t=5 \mathrm{sec} \Delta t=10 \mathrm{sec} \Delta t=20 \mathrm{sec} \Delta t=30 \mathrm{sec}$ (e)

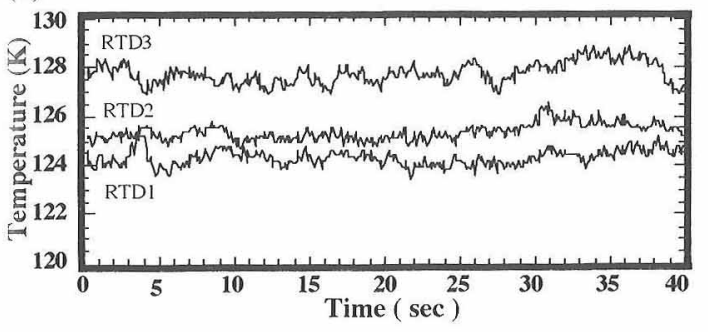

Fig. 3 Pictures of the infinite interferogram and time variation of temperature in the case of $q=0 \mathrm{~W} / \mathrm{m}^{2}$. Figure 3e shows the data when the picture shown in Fig. 3a was obtained.

分解能 $\Delta \mathrm{T}$ が臨界点で限りなく上がることから説明で きる. また, Fig. 3b〜3d から，セ儿底部付近で明瞭な 干渉縞が形成される過程が観察できるが，これは空か らの熱輻射により，七ル底部が温められたため現れた ものと考える. Fig. 3e の温度データから分かるように， 実験セル上部は下部に比べ，温度がおよそ $3 \mathrm{~K}$ 程高く なっており，特に中央部から上部にかけて大きな温度 勾配が付いていることが分かる。このセル内部の温度 勾配は対流の発生を抑制させる方向に㗢く，また，可 視化写真の捕らえた熱輻射による温度上昇は, 温度計 による温度データのノイズの範囲内に埋もれてしまう 程度の大きさであることが分かる.

Fig. 4 に $\mathrm{q}=586 \mathrm{~W} / \mathrm{m}^{2}$ の加熱を行った時のホログ ラフィー画像と温度データを示す. 温度データ中の点 線は第二露光時の時間を表している. ちなみに, ここ で加えた熱量は前報で報告した実験セル底部から加熱 を行った時の最大加熱量の約 1.6 倍に相当し，この時 $の \Delta \mathrm{t}=30 \mathrm{sec}$ の画像では, 半分以上が対流領域で占め られた ${ }^{12)}$. しかし, この場合, 加熱量がそれより大 きいにも関わらず，干渉縞の生じない領域は天井板に 設置したヒーター面の極く近傍のみで，ほぼ完全に自
然対流の効果は抑制できていることが分かる．Fig.4a のホログラフィー画像を Fig. 3a と比較すると, 加熱

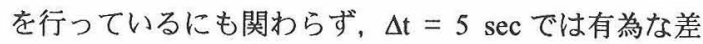
は見受けられない。しかし，Fig.4b〜4d の画像から， 時間の経過に従い実験セルの上部での干渉縞の間隔が Fig.3b〜3d の場合に比べ，拡がってきていることに気 付く. 次に, 温度デー夕を見ると, ヒーター面上に設

(a)

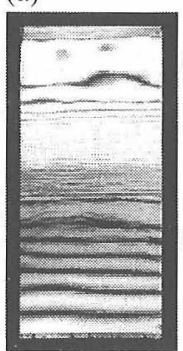

(b)

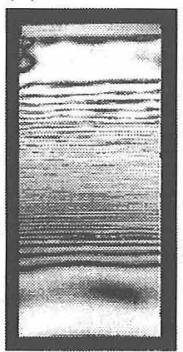

(c)

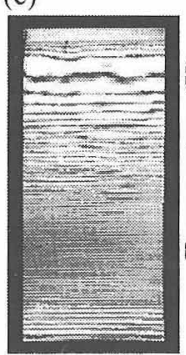

(d)

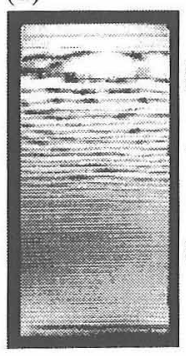

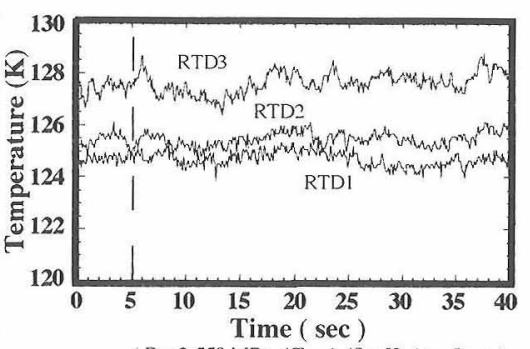

$(\mathrm{P}=3.550 \mathrm{MPa}, \Delta \mathrm{T}=1.48 \mathrm{mK}, \Delta \mathrm{l}=5 \mathrm{sec})$

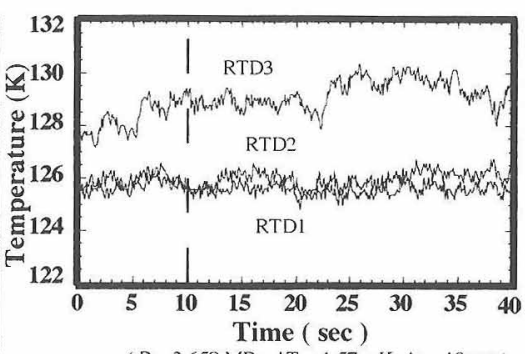

$(\mathrm{P}=3.658 \mathrm{MPa}, \Delta \mathrm{T}=1.57 \mathrm{mK}, \Delta \mathrm{t}=10 \mathrm{sec})$

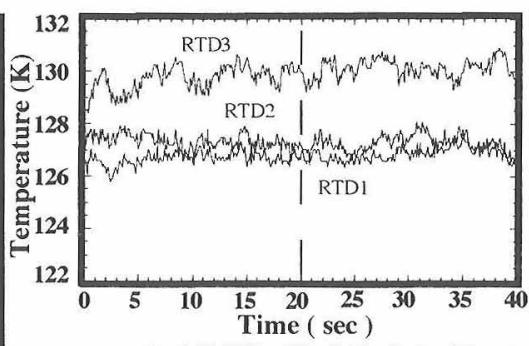

$(\mathrm{P}=3.766 \mathrm{MPa}, \Delta \mathrm{T}=0.67 \mathrm{mK}, \Delta \mathrm{t}=20 \mathrm{sec})$

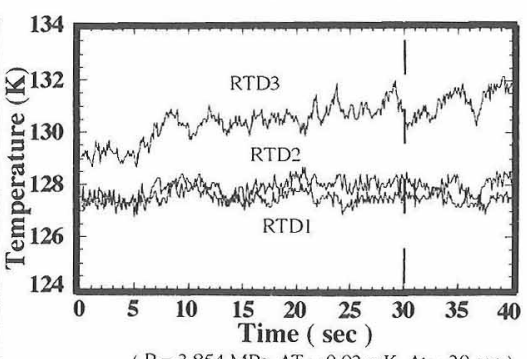

Fig. 4 Pictures of the infinite interferogram and time variation of temperature in the case of $q=586 \mathrm{~W} / \mathrm{m}^{2}$. 
置した RTD3 の温度に，30 sec 後で約 $1.5 \mathrm{~K}$ 程の温度 上昇が認められるが，RTD2 とRTD1 からは加熱に対 する温度上昇は特に認められない。

Fig. 5 は q = $1131 \mathrm{~W} / \mathrm{m}^{2}$ の加熱を行った時のホログ ラフィー画像と温度データを表す。まず，ホログラフ イー画像から，基本的には Fig. 4 で示した画像と同様 の変化を示していることが分かる，しかし，Fig.5c，5d

(a)
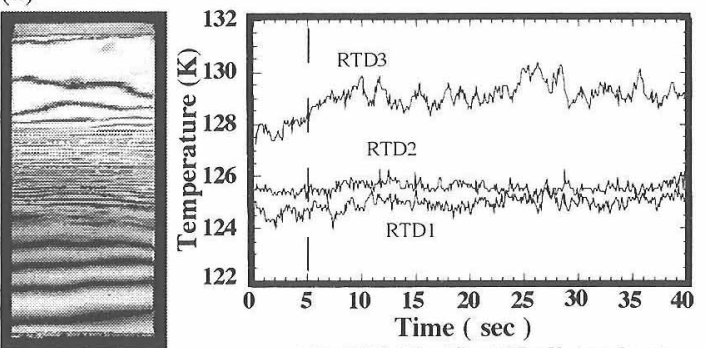

(b)
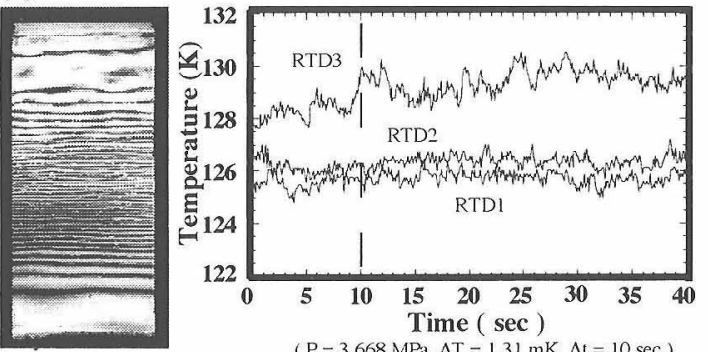

(c)
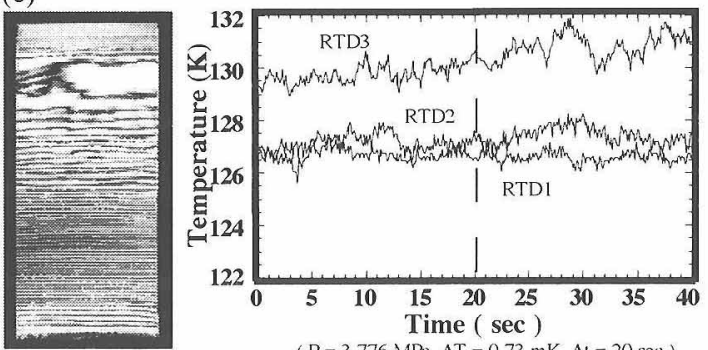

(d)
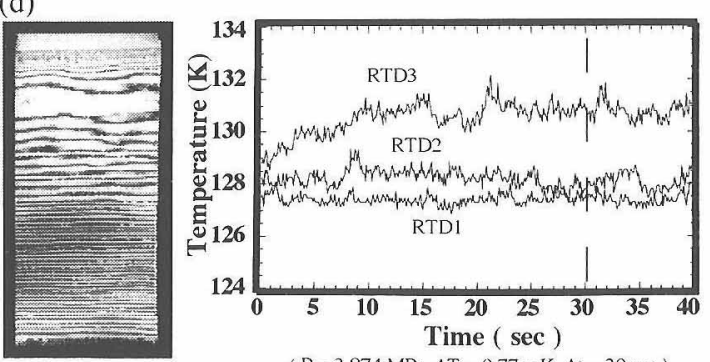

$(\mathrm{P}=3.874 \mathrm{MPa}, \Delta \mathrm{T}=0.77 \mathrm{mK}, \Delta \mathrm{t}=30 \mathrm{scc})$

Fig. 5 Pictures of the infinite interferogram and time variation of temperature in the case of $q=1131 \mathrm{~W} / \mathrm{m}^{2}$.
のホログラフィー画像から，実験セル上部の干渉縞の 間隔が Fig. 4c，4d のそれに比べ，更に拡がってきて いることが分かる，一方，温度デー夕からは，ヒータ 一面上の温度が Fig. 4 に比べ更に上昇していることが 分かるが,その他に関しては特に差異は認められない。

次に $\mathrm{q}=3334 \mathrm{~W} / \mathrm{m}^{2}$ と更に大きな加熱を行った場合 の実験結果を Fig. 6 に示す。 まず，ホログラフィー画 (a)

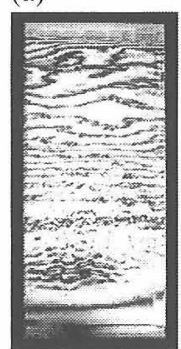

(b)

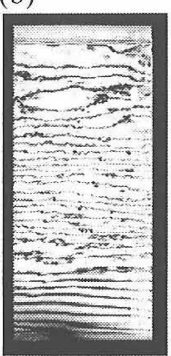

(c)

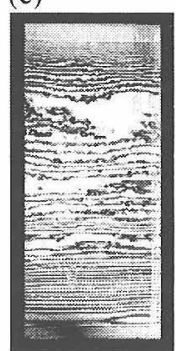

(d)

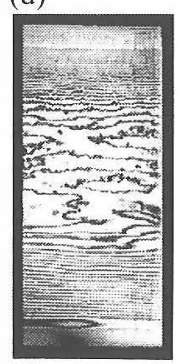

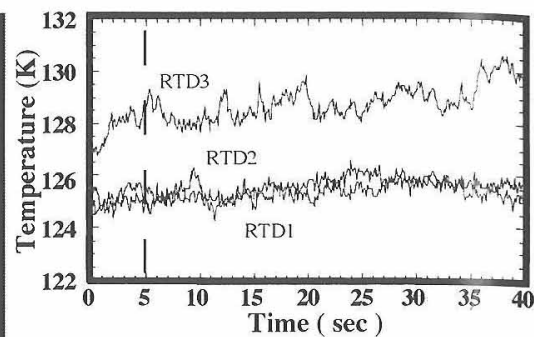

$(\mathrm{P}=3.589 \mathrm{MPa}, \Delta \mathrm{T}=1.86 \mathrm{mK}, \Delta t=5 \mathrm{sec})$

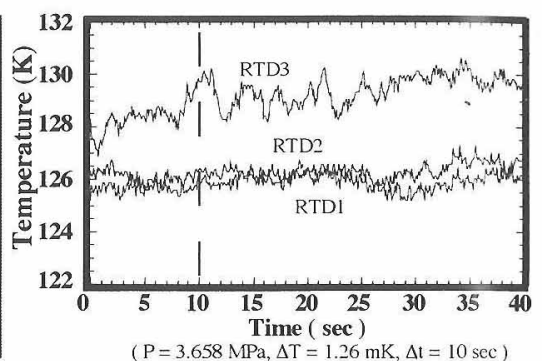

$(\mathrm{P}=3.658 \mathrm{MPa}, \Delta \mathrm{T}=1.26 \mathrm{mK}, \Delta \mathrm{t}=10 \mathrm{sec})$

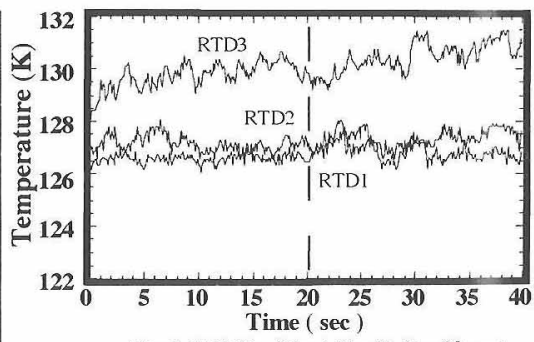

$(\mathrm{P}=3.776 \mathrm{MPa}, \Delta \mathrm{T}=1.51 \mathrm{mK}, \Delta \mathrm{t}=20 \mathrm{sec})$

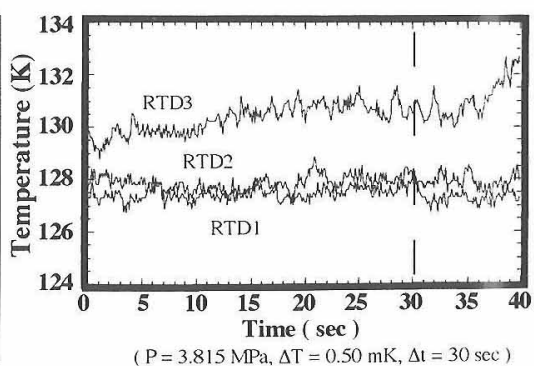

Fig. 6 Pictures of the infinite interferogram and time variation of temperature in the case of $q=3334 \mathrm{~W} / \mathrm{m}^{2}$. 
像に明らかな変化が現れてきていることが分かる. Fig. 6a の画像は $\Delta \mathrm{t}=5 \mathrm{sec}$ 時のものを示しているが, これ までの画像は気液界面の存在していた所に干渉縞が集 中していたのに対し，この画像を見るとその位置にあ る干渉縞の間隔が明らかに広くなっていることが分か る. Fig. $6 \mathrm{~b}$ の画像は $\Delta \mathrm{t}=10 \mathrm{sec}$ の時のものを示すが, ここで得られた干渉縞のパターンは実験セル上部の干 渉縞間隔が拡がつた Fig. $5 \mathrm{~d}$ で示した画像パターンと 非常に似ていることが分かる. Fig. 6c では更に, 干 渉編の間隔が拡がってきており, Fig. 6d に至っては 更に, 実験セル中央部の広い範囲に渡り干渉縞間隔の 拡がった領域を観察することができる．この干渉縞の 拡がった領域では温度変化がほとんどないことを表し ており,このような領域の発達・形成はピストン効果 でしか現れない特徵である. また, その両側では干渉 縞が集中し上下に対象なパターンが現れて来ているこ とが分かる. 画像の上下において一見, 干渉縞が写真 から見てとりづらい領域があるが，ヒータ一近傍を除 き乾板上には干渉縞が密に刻まれている.再生段階で, 隣り合う干渉縞どうしが干渉しあい，うまくこれを捉 えることができなかったことから，そこでの干渉縞が 見てとりづらくなっている. しかし, 実験によりピス トン効果の特徵である急峻な温度勾配の存在も確認す ることができた. なお，ヒーター面近くに関しては, 手前側と奥に位置する空とヒータ一両端との間に隙間 が存在するため, ヒーターの両端近くで対流が生じ, 干渉縞が観察できない領域が現れたと考える. 一方, 温度データからヒーター面上で大きな温度上昇が認め られるが, 中央部や下部の温度は Fig. 4 や Fig. 5 で示 したものと有為な差は認められなかった. よって, ヒ 一ター面のごく近傍では大きな温度差が付いており,

下部側の温度差は上部側に比べ, そう大きなものでは ないことが分かる.

これらの実験から推察できる Fig. 6d の状態におけ る定性的な温度分布, 及び密度分布を Fig. 7 に示す.

Fig. 7a は加熱前の第一露光時の温度分布と密度分布 を, Fig. 7b は加熱後の第二露光時の温度分布と密度 分布を示す. Fig. 7b と Fig. 7a の温度, 又は密度分布 の差が Fig. 6d のホログラフィー画像中に見られる干 渉縞として現れている. 本実験ではヒーターの加熱量 を増やすことによりピストン効果を顕著に捉えること ができた. ピストン効果の発現に寄与するパラメータ として式(4)にある等温圧縮率, $\alpha_{\mathrm{T}}$ が挙げられる.これ は臨界点において無限大になる熱物理学量である. 本 (a) Before heating (1st flush)

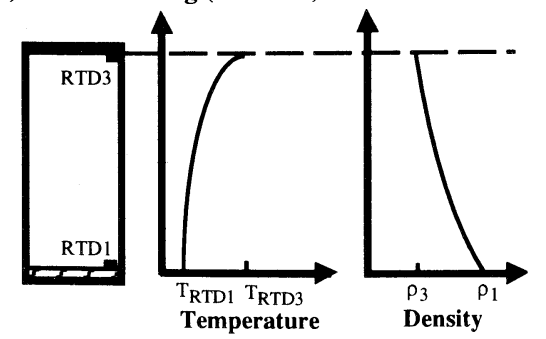

(b) After heating (2nd flush)

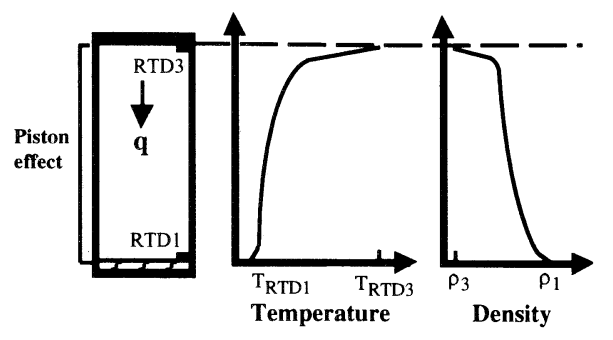

Fig. 7 Schematic illustrations of the temperature distribution and density distribution in the experiment.

実験条件のように温度及び圧力がある程度, 臨界点か ら離れると $\alpha_{\mathrm{T}}$ のピストン効果発現への寄与が小さく なる. よって, ピストン効果を明確に捉えるために, このように大きなヒーターからの加熱が必要になった と考える. しかし，一方，大きな加熱を行ったがため に得られた画像データから全ての干渉縞の本数を数え ることができなかったため, 定量的な解析を行うまで には至らなかった。 しかし，ピストン効果による特異 な温度場の形成過程を地上実験において初めて可視化 し，これを捉えることに成功したと考える. 今後は実 験条件を考慮した数値計算を行い，ここで得られたデ 一夕との比較を行ってゆく予定である.

\section{5. まとめ}

臨界点近傍における超臨界流体中で現れる熱輸 送現象「ピストン効果」の可視化をレーザーホログ ラフィー干渉計を用いて試みた. 重力による自然対 流の発生を抑制するため, 超臨界窒素実験セルの天 井板に平板ヒーターを設置し, 加熱面を下に向けス テップ的な加熱を行い可視化実験を行った. その結 果, ピストン効果により形成される温度分布の特徵 を捉えることに成功し, 地上実験でこの熱輸送現象 の可視化に成功した. 


\section{参文 献}

1) K. Nitche and J. Straub : Proc. of 6th European Symposium on Material Sciences under Microgravity Conditions, ESA-SP-256 (1986) 109

2) H. Klein and B. Feuerbacher : Phys. Lett. A 123 (1987) 183

3) P.Guenoun, B. Khalil, D. Beysens, Y. Garrabos, F. Kammoun, B. Le Neindre, and B. Zappoli : Phys. Rev. E. 47 (1993) 1531

4) A. Onuki, R. A. Ferrell : Physica A 164 (1990) 245

5) B. Zappoli, D. Bailly, Y. Garrabos, B. L. Neindre, P. Guenoun and D. Beysens : Phys. Rev. A 41 (1990) 2264

6) T. Maekawa, K. Ishii : Thermal Science and Eng. (The
Heat Transfer Soc. of Japan) 5 (1997) 15

7) T. Frohlich, P. Guenoun, M. Bonetti, F. Perrot, D. Beysens, Y. Garrabos, B. Le Neindre and P. Bravais : Phys. Rev. E 54 (1996) 1544

8) 東 久雄: 伝熱研究 36 (1997) 9

9) H. Boukari, J. N. Shanmoyer, M. RE. Briggs and R. W. Gammon : Phys. Rev. A 41 (1990) 2260

10) F. Zhong and H. Meyer: Phys. Rev. E 51 (1995) 3223

11) F. Zhong and H. Meyer : Phys. Rev. E 53 (1996) 5935

12) 中納暁洋, 白石正夫, 染矢聡, 西尾匡弘, 飯田光 人, 村上正秀 : 低温工学 35 (2000) 79

13) A. Nakano, M. Shiraishi, M. Nishio, F. Takemura and M. Murakami : Adv. in Cryog. Eng. 43 (1998) 1297

14) L. D. Landau and E. M. Lifshitz 著, 竹内均訳 : 流 体力学 1 , 東京図書 (1992) 